\title{
Rob Matsuda, musician
}

Rob Matsuda is a violinist who has contributed to film and television scores since 1996, including the feature film The Horse Whisperer (1998) and the blockbuster television series Lost (2004-10). A member of the Union of Professional Musicians, Local 47, in Los Angeles, Matsuda recalls the heyday of motion picture musicians and describes the ways in which producers have moved much of the work overseas or resorted to licensed pop songs or computergenerated music.

How did you get your start with orchestral soundtracks? Your first film was The Horse Whisperer, correct?

I did a film before that in which my friend put together the musicians for a Pauly Shore movie called Bio-Dome (1996). Interestingly enough, the residuals for BioDome went on, and on, and on. At the back end, it actually paid better than The Horse Whisperer. I'm probably still getting checks for Bio-Dome. It was officially my first movie project.

How did you get your foot in the door?

When I was a teenager studying the violin, I had a teacher, Mr. Chassman, who was part of the Fox orchestra back in its heyday. You can see him in the Marilyn Monroe movie How to Marry a Millionaire (1953). He would tell me about playing for the movies while I was at my lessons. It sounded like a really great thing! You'd be playing your instrument, and it would allow you to make what I assumed 
would be a comfortable middle-class living. I knew that was what I wanted to do when I grew up.

Bio-Dome came out in 1996, and I got that job after about ten years of going around playing for concertmasters and contractors and trying to get my foot in the door. When people ask, "How do you get started?" I have to disabuse them of the notion that there's a clear-cut way of getting into this kind of work, at least what's left of it. And it's different for everybody, because it's not like applying for a job at an insurance company.

I got the Bio-Dome job because I was a friend of the contractor who got the job because he was a friend of the composer. They both attended the same high school when they were younger.

\section{That got you started. What kept your career going?}

I had a good stretch of work after Bio-Dome, until 2006. I got my position on The Horse Whisperer through a connection with the composer's family. I had been working with volunteers for about ten years at the Los Angeles County Museum of Art (LACMA), and the word got around that I was a violinist. One of the volunteers was related to the composer for The Horse Whisperer, and she put in a good word for me. I owe that job to her. Then, once I was playing for him, I started getting hired to play on his other films and things expanded from there. It's critical for instrumentalists to end up on a contractor's list. They are responsible for hiring people to play in the orchestra.

\section{How do you get on a contractor's list?}

It's a nebulous process. There are so many ways! You play for people, like the lead violinist, who is called the concertmaster. Of course, those people have an inflated sense of their own power. People have to play for them; they're the gatekeepers who make recommendations to the contractor. My entrée was through a family-work connection. The composer then told the contractor to contact me. And of course people know each other from school, "Oh, I went to Juilliard with so and so." They recommend you to the contractor. People even say there's a casting couch.

When composers are young and they're trying to make it, they need a reel. They need projects to work on, and they often seek out student filmmakers at film schools. The composers don't make much money, which means they can't pay the musicians much, if anything at all. Oftentimes they will ask musicians to volunteer: "I don't have a lot of money, but I'll buy you pizza. Can you help me score the short film I'm working on?" Musicians will agree to do the work in the hope that the composer's profile in the industry will rise and that they'll take you along for the ride. But that doesn't always work. In fact, a major beef with my colleagues 
is that they'll play for free! Worst of all, when people you play for become more successful, they tend to forget that you once did them a favor. Of course, I imagine that if there's a lot of money on the line and if the young composer has a choice between working and not working, they'll say to the contractor: "Okay, fine, just take care of it. I'm sorry I have to leave Robert and his friends behind, but, this is my chance." So, it's a complex process.

By the way, the same can be said about contractors. They might use you onceif it is helpful to them-and never hire you again.

So the contractor is a central gatekeeper.

They're like Saint Peter, they are so powerful. In fact, there are one or two who are enormously powerful and influential. For a long time during the 1970s, 1980s, and 1990s, there was one woman named Sandy DeCrescent who controlled access to 90 percent of the work. She retired, and one of her assistants, Peter Rotter, took over. Then he controlled 90 percent of the work. At some point after the transition, Sandy and Peter got into an argument over some business or personal matter. Now she's back in the game, and they're mortal enemies! I've never seen them. To me, they're like the Wizards of Oz. I'm not in the 90 percent world. I'm in the 10 percent world. And for a good stretch of time, 10 percent was pretty good. But now, that amount of work is so much smaller that it breaks down to almost nothing.

Do contractors tend to hire the same people? Do orchestras stick together from film to film?

Contractors put together an orchestra for each film. And there are contractors who attach themselves to certain composers. So this creates a degree of expectation: if you played on one composer's film, you will likely play for all of their films. Composers like to work with people they know and trust; so do contractors. But there are no guarantees.

\section{When contractors reach out to people, are they asking for an audition?}

No, they know you already. They know they want you. It's more of a conversation about money, time, and availability.

When you were working consistently, how often were you working?

Before I did The Horse Whisperer, I was working at LACMA, so I didn't live on my music work. I would do community orchestras, weddings, and any kind of live music work that I could get. Even after The Horse Whisperer I still wasn't getting 
enough work to quit the museum, but by that time I had accumulated so many sick days, vacation days, and free days that LACMA wanted me to take days off. That was great because I would get a paid day off and be able to do a movie.

I met my mentor, Harris Goldman, on The Horse Whisperer. I was very fortunate to meet him; he had great relationships with many different composers and orchestrators. Orchestrators are important because they often write the music for a film based on the composer's ideas. Orchestrators possess the technical knowhow to translate those ideas into sheet music. Connections to composers and orchestrators are helpful-obviously they're both powerful, and they can make recommendations to the contractors. Harris introduced me to Graeme Revell, who has since retired. He also introduced me to a young composer named Michael Giacchino, who is huge now. I think I did his first non-video-game project, which was the TV series Alias (2001-6). Alias led to Lost. For a while, Lost and Alias were on at the same time, and then he started doing movies-Pixar movies like The Incredibles (2004), Ratatouille (2007), and others.

So, right there, I had access to Thomas Newman on some good films. I was doing Pixar movies and any other movie that Michael Giacchino was doing, and during a brief period, I was doing both Alias and Lost. One week I'd go in and do Alias and the next week I'd do Lost. And then Alias went off the air, but I still had Lost.

\section{Can you describe a typical day?}

For episodic television, it's a short day. An episode of TV for an hour-long show like Alias or Lost, which is called a single, usually requires three hours: typically from ten in the morning to one in the afternoon, with a ten-minute break at the top of each hour. For a motion picture, there's more footage that needs to be scored, so depending on the nature of the film, it could be one day, known as a double session. That could mean about six hours with a lunch break, or it could mean a whole week.

\section{Do studio musicians need a second income?}

I would say the most successful people have a regular flow of studio work across film and television. But they also teach and play in other orchestras, like the opera or the Los Angeles Chamber Orchestra. However, they always have studio work at the core of their career.

\section{How much can you make in a recording session?}

If it is a standard budget, a rank-and-file musician can make about $\$ 80$ an hour. That's not bad, and you get money on the back end as well. There is also 
low-budget, and now something called low-low-budget, which pays considerably less.

\section{What is the back end?}

Some office in Encino tallies it up, and it's predicated on things like video sales, DVD sales, and what happens overseas. They tally all of the projects that you have worked on and your percentage of royalties, and then you get a check in the summertime. You get one check for film and television, and a smaller check the next month for any kind of phonograph work you've done. (They still say "phonograph" even though it's an incredibly outdated term.) It refers to work you've done on commercial music, like albums or singles.

With your check, you get a long itemized statement, and it behooves you to look at it closely to see if they missed anything. It happens. But it's also really interesting to see the different trends across the film and television you've done. Like I said, I'm still getting money from old projects like Bio-Dome. It's maybe \$10, but it's money! Other films have a huge drop off. For instance, Star Trek (2009) made some good money at first, and then the next year it went down a little, and then down, down, down, down very quickly. It was a rapid drop.

Both Lost and Alias made a lot of money in international and ancillary markets. Over the course of time, how much money could you expect in residuals?

It was pretty good money. It wasn't astronomical like it is with some movies, but it was always a nice check. I don't recall exact amounts, but the back end on those shows could pay your rent for the month. It's always surprising what pays well on the back end. Some projects that you think wouldn't do well end up paying you the most.

For example, I have a friend who did a sidelining job on the movie I Love You, Man (2009). He was playing in a quartet at the wedding at the end. Sidelining means you appear on camera, almost as an actor. Usually you're miming to prerecorded music; you're just there as a visual. And nobody wanted to take the job! You had to go up to Malibu every day and be there really early, and it just didn't seem like a terribly good job, but because there was no other scored music-every other song on the soundtrack was a pop song-they got this large sum of money! Divided among the four of them, they got really, really good money on the back end.

Another friend, a bass player, had an appearance on a Chili's commercial. He was playing the bass with a jazz singer. When he first heard about the job, he wasn't going to audition for it, but we convinced him. I think when everything wrapped up he probably made $\$ 10,000$ for that, which is excellent for essentially one day's work. 
When you look at the itemized list of residuals, what have been some of your biggest surprises, other than Bio-Dome?

A movie that paid very well was The Incredibles. We knew that it was going to make some good money because it was very successful. But it was worth thousands of dollars for me! Everybody was asking about it: "Did you get your check for that?" Because, you know, not everybody is in that top echelon of musicians, where they're working for everyone all the time. A lot of the musicians in Los Angeles are just like me, waiting for that elusive studio call, which has become more and more rare.

What happened? You said you started to notice a change around 2006 or 2007.

What happened was just an acceleration of trends that were already in place. Costs all come out of the producers' pockets. I only make scale, but other people in the orchestra, say a section leader, get double scale. And if a contractor hires someone we call a doubler-someone who is hired to play more than one instrument-scale pay is automatically higher. Plus, the contractor could be making double or triple scale. So it all starts to add up before you even calculate the back end, which also increases depending on your scale pay. I think producers began to say, "This is an unnecessary expense. Let's go overseas. Let's go to London.” They have nationalized health care so there are no benefit costs for producers. They don't pay any residuals. There is no union. The musicians just get paid their hourly rate for their time in the studio.

George Lucas has all of his films done in London. He has always been virulently antiunion. On the other hand, Thomas Newman has always been committed to scoring his films in L.A. He comes from a film music dynasty, so I think he has a strong sense of loyalty to keeping business in the city. He is loyal to musicians here. His father was Alfred Newman, his uncle was Lionel Newman, his cousin is Randy Newman, and his brother is David Newman. Nevertheless, he got the 007 franchise, and that does not leave England, so now he has to go over there and use their musicians.

Of course London has a lot of incredibly talented musicians. But if you're already in the London Symphony Orchestra, you have that work, so film jobs are just extra cash. Even if you're not in the London Symphony Orchestra, or the four or five other orchestras there, there are lots of opportunities. From what I understand, Abbey Road and Air Studios are open night and day, seven days a week. It's incredibly busy. Freelance musicians are scoring films or video game soundtracks. Video games are a huge market now! Some of them have better production values than motion pictures. I did some of that ten years ago. I started working on Call of Duty and Medal of Honor. We basically created motion picture soundtracks, using 
a big orchestra. But the video game companies have become even more tightfisted about residuals and in negotiating with the unions. They're basically saying, "We don't need to do this anymore."

Whatever pugnacious tactics the unions had unfortunately weren't enough to prevent studios from going either overseas or out of state to find musicians who would accept their terms. I think Seattle was the first city to break away from the national union.

\section{How pugnacious was the union when this trend started?}

I think it was mainly verbal. I don't think there was a lot of punch behind it, compared to the other [motion picture] unions. The musicians' union doesn't have as much power. When writers go on strike, you have no content, so things grind to a halt. But when musicians go on strike, they say, "Well, we'll just go out of town."

Why is it so easy to go out of town? Don't directors and producers want to be closer to the action when they're in postproduction, to oversee the development of the soundtrack?

You would think, but then you have to consider the money, and that's all the producers and studios are worried about right now. A studio is just a distribution channel owned by a much larger global entity. And because they're multinational corporations, they have to answer to the bottom line. The executives who run these multinational corporations likely have no interest in film music or where it is done. They just have to answer to shareholders. Accountants have much more power than they used to. Can you save money by going to London, or the Czech Republic, or Macedonia, or Seattle? If so, we'll do it!

Where do they go? We know about London and Seattle.

The Czech Republic is very big.

\section{Why the Czech Republic?}

It's an incredibly musical place. Mozart in his time was more popular in Prague than in his native Austria. The country has a rich tradition of symphonic music that includes Antonin Dvořák and other Czech composers. And the cost of living is lower there, so wages are lower, and producers don't have to pay into health care. They don't have to pay the back end. You just have to pay the musicians for their time in the studio. 


\section{What other places?}

Well, that's enough to sink the ship. But London is the biggest, by far. Dreamworks Animation is 100 percent London. Until the latest Star Wars, George Lucas did his recording in London. The new one was done here in L.A., but I don't know why.

Besides the battle over payments, what else is making jobs disappear?

I think our tastes in music have changed. When you turn on the radio now and listen to Selena Gomez or Katy Perry, oftentimes you're not even hearing real instruments. Those songs are purely electronic productions done by producers. People don't expect strings or real instruments backing up the artist. Recorded music also has good sampling. A very good producer or somebody with a suitable keyboard can get what passes for a good string sound, and the samples are getting better and better. People don't expect to hear a natural, acoustic-sounding backdrop when they hear popular music these days. Those jobs used to be important sources of money when you weren't doing film or television work.

Now you only expect to see violins or symphonic instruments, as a visual. If Michael Bublé is doing something on PBS, you may see actual instruments and musicians like me. Or if they're doing a studio session, I might get a call. But when it comes time to do it live, they don't want to see me. Directors will probably try to get a pretty, willowy, young, white, blond woman to put on the set. Somebody's getting the work, at least, but it's not me.

We had no idea this transition has been afoot. It's startling, especially when you consider the significant role that music plays in most Hollywood films.

Oh, there's no reason to apologize. Musicians are invisible, so things can happen to the musicians and the general public doesn't know. That's why I'm so eager and willing to go on record, or talk to people about changes in our business. I don't want to be in politics or anything, but I do want to tell people that musicians do exist, and I want to emphasize that when you hear music in a motion picture, it's played by real people. Sometimes the music is done so incredibly well, like with Thomas Newman, that it becomes part of the narrative. The music is essential for propelling the narrative of the film.

I think the whole transition has been manipulated in very clever ways, even through union negotiations. Like I said, unions don't have a ton of power, so when they capitulate, they often turn around to frame it as a benefit. They'll say, "We have this new agreement with the studios where a certain amount of work has to be done in town." On the surface that sounds great! But the studios still determine what work stays and what work goes. So they'll do a bunch of films 
like Attack of the Killer Tomatoes: Part VIII in L.A., and take prestige projects elsewhere. There's a very tangible difference for musicians between working on a low-budget feature versus a big-budget prestige project.

In another interview, you were quoted as saying that access to job opportunities is now extremely political. Can you elaborate?

We had various watering holes in our business. I had my watering hole with a few other animals. Other animals were at different watering holes. I was at the Thomas Newman-Michael Giacchino watering hole. It turned out to be a good watering hole to have, but now these other watering holes, which provided a lot of work, have dried up and those animals are coming over to my watering hole, and the more politically and powerfully connected musicians have the ability to push me aside, if they want.

\section{What kind of scoring work is still done in L.A.?}

Luckily for me, two of the composers who still score here are Thomas Newman and Michael Giacchino, and there is some pop music that needs strings. If you Google my name you'll see some of the sound-not soundtrack but phonograph-work I've done. I'll do work for artists like Beck. Beck's father, David Campbell, is an orchestrator. So, right there, Beck has an in-house person to do string arranging for his records. But that type of work is increasingly rare. Today it's mostly when a producer wants some strings to make something more romantic. They call it sweetening. If a popular artist like Katy Perry does a ballad, that's good for us because we might get the call for that, but again, that doesn't happen all that often. It's just not the predominant sound in popular music. They needed strings more often during the disco era. My god, you listen to a disco album that was recorded in the mid- to late 1970s and everything has strings.

A lot of the work that made for a middle-class living was not particularly prestigious. It was just work, and there was a lot of it. For instance making commercial jingles for Safeway, and things like that. Back then they used real musicians for jingles. The only time you'll hear an orchestra on television now is when you watch The Simpsons (1989-ongoing), Family Guy (1999-ongoing), and maybe one or two other animated things. Animation seems to require real musicians. Desperate Housewives (2004-12) used an orchestra when it was on the air, but since the demise of Alias and Lost, I don't think there's been a lot of orchestra work for non-animated TV.

It's just not looking good for musicians. People are taking early retirement and taking their pensions. All it requires is that the musician not accept any work for a year, and then he or she can start getting pension payments. If work does come in 
after that, you can take it, but that means we are essentially bankrupting our pension fund. My royalty check is being taxed at 1 percent, which then contributes to the retirement fund, which is currently in the red. Hopefully the union can rebuild the coffers, but right now we don't know if there will be any money left when my peers and I are ready to retire. I just assume I'm going to somehow continue working when I'm ninety years old. Let's hope I'm able to!

\section{What are you doing today?}

I'm lucky that a couple of my friends made a financial intervention. They took me out to lunch and reminded me that I inherited my parents' house after they both died in 2011. Since then, I had been living in their house and slowly going broke. They said, "You live in a great house. You have a swimming pool, a view of the city, and you're in Los Feliz. Fix up the house and rent it." Even though I was still grief stricken, I said, "Okay, I'll do it." I got a loan, fixed up the house, and got a realtor.

There were a couple of offers that fell through and then somebody I had heard about and liked from the entertainment industry came and loved the house. $\mathrm{He}$ was a novelist for many years prior to becoming a showrunner. One of his stories got made into a TV show and that totally changed his life. Now he was working on another show, so he decided to move to L.A., and he rented my house. I'm not out of the woods, but at least I'm able to pay for an apartment down the hill from my house and start paying off my debts. I hope he stays there forever; he's a great guy.

So the pressure has eased somewhat. Now I view myself more as a landlord than a musician sometimes. Some musicians say you have to do things like that, and a couple of players I know became real estate agents, but that profession is also subject to the market's whims. Some older players have also invested in property, so I have this little thing with the house and hopefully there'll be a point where I'm no longer paying off the debt. I'm getting money from whatever is left from my movie, television, and phonograph work. I'm sorry I can't paint a brighter picture for you guys, but hopefully this was helpful in some way. 